\title{
Aktualny stan wiedzy dotyczący zagadnienia bezpieczeństwa przed wykolejeniem
}

\begin{abstract}
$W$ artykule przedstawiono aktualne informacje dotyczace bezpieczeństwa przed wykolejeniem kolejowych pojazdów szynowych, zebrane na podstawie norm europejskich, opracowań komisji ORE, kart UIC, Technicznych Specyfikacji Interoperacyjności oraz przepisów krajowych. Opisano istote wspótczynnika bezpieczeństwa przed wykolejeniem, sposób do jego obliczeniowego wyznaczania oraz metodykę badań doświadczalnych.
\end{abstract}

\section{Wprowadzenie do problematyki}

Do lat 60. XX wieku problemem bezpieczeństwa przed wykolejeniem nie zajmowano się w szerszym zakresie. Dopiero po serii wykolejeń krytych wagonów towarowych nowej konstrukcji, charakteryzujących się zwiększoną sztywnością w stosunku do dotychczasowych konstrukcji, zaczęto poszukiwać rozwiązania tego problemu. W tym celu powołano grupę badawczą B55, wchodzącą w skład ORE / ERRI (Office for Research and Experiments of the UIC / European Rail Research Institute), której efektem pracy był raport Rp.5, określający kryteria bezpieczeństwa jazdy wagonów towarowych po torze zwichrowanym. [7]

Obecnie bezpieczeństwo przed wykolejeniem stanowi jeden z parametrów sprawdzanych podczas badań homologacyjnych nowego oraz modernizowanego taboru kolejowego. Procedury pomiarowe oraz mierzone wartości zostały określone w normie europejskiej EN 14363:2007, mającej status polskiej normy. [4] Poszczególne etapy procedury homologacyjnej kolejowego pojazdu szynowego zostały przedstawione na schemacie na rys. 1.1.

Cały proces homologacyjny składa się z trzech głównych etapów. W pierwszej kolejności dokonuje się sprawdzenia podstawowych parametrów konstrukcyjnych, określonych w dokumentacji projektowej. Jest to etap weryfikacji projektu na zgodność z obowiązującymi przepisami i normami. Po jego przejściu pojazd kierowany jest na próby stacjonarne, które sprawdzaja jego przystosowanie do jazdy. W ich zakres wchodzi pomiar momentu obrotowego wózka, pomiar statycznych, pionowych nacisków kół na szynę na torze prostym, pomiar kołysania pudła oraz określenie współczynnika bezpieczeństwa przed wykolejeniem.

Po zakończeniu prób statycznych z wynikiem pozytywnym badany pojazd kierowany jest na próby ruchowe. Przeprowadzane są one po uzgodnieniach $\mathrm{z}$ właścicielem infrastruktury kolejowej i odbywają się na normalnej linii kolejowej, użytkowanej w prowadzeniu rozkładowego ruchu pasażerskiego i towarowego. Odcinek takiej linii powinien spełniać wymagania, określone w normie [4].

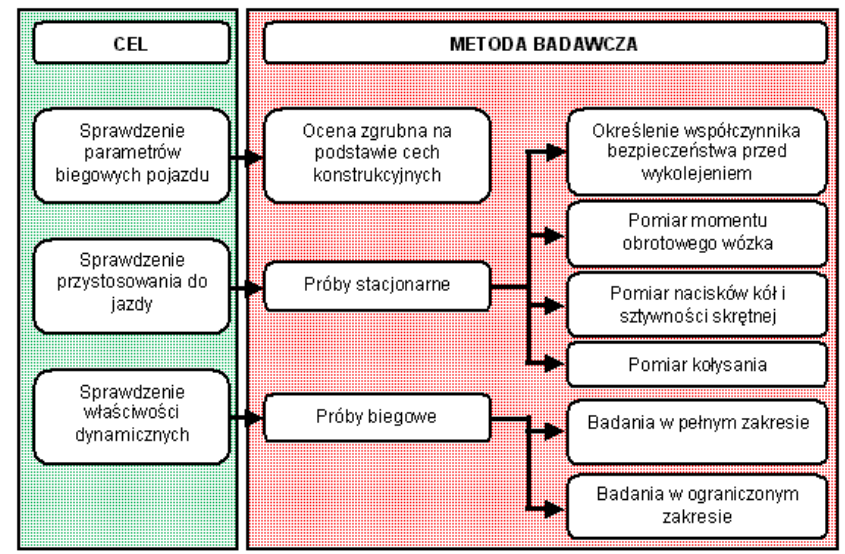

Rys. 1.1. Etapy procedury homologacyjnej kolejowego pojazdu szynowego. Opracowano na podstawie [4]

Próby biegowe przeprowadzane są $\mathrm{w}$ dwóch zakresach: pełnym lub ograniczonym. Pełny zakres prób dotyczy pojazdów nowych, w których zastosowano nowe rozwiązania technologiczne. W przypad$\mathrm{ku}$, gdy do badań wyznaczany jest pojazd zmodernizowany, częściowo przebudowany lub będący częściowo zunifikowany z istniejącymi już pojazdami, które posiadaja świadectwa dopuszczenia do ruchu (jak np. w przypadku kolejnej wersji konstrukcyjnej jednego typu wagonu kolejowego) można stosować ograniczony zakres badań.

Jednym $\mathrm{z}$ elementów prób stacjonarnych jest określenie współczynnika bezpieczeństwa przed wykolejeniem. Miarodajne jest wyznaczenie tego współczynnika na torze badawczym (z wichrowatością lub bez wichrowatości) lub na stanowisku badawczym poprzez wyznaczenie odciążenia koła $\Delta \mathrm{Q}$ w oparciu o próby wichrowania oraz obliczeniowe wyznaczenie 
wartości siły prowadzącej Y. Istnieje również możliwość obliczeniowego określenia wartości współczynnika bezpieczeństwa przed wykolejeniem na podstawie znajomości wybranych parametrów konstrukcyjnych pojazdu. W dalszej części artykułu zostanie przedstawiony aktualny stan wiedzy dotyczący bezpieczeństwa przed wykolejeniem pojazdów szynowych.

\section{Istota wspólczynnika bezpieczeństwa przed wykolejeniem}

Podczas wjazdu pojazdu szynowego w huk toru w miarę zmniejszania się promienia krzywej przejściowej toru zmniejsza się luz pomiędzy obrzeżem a główką szyny. Po jego wyczerpaniu koło styka się z szyną w dwóch miejscach na profilu koła. W wyniku dalszego zmniejszania się promienia i zwiększania się przechyłki toru koło może unieść się na obrzeżu, tworząc styk jednopunktowy. Układ sił po uniesieniu koła został przedstawiony na rys. 2.1 .

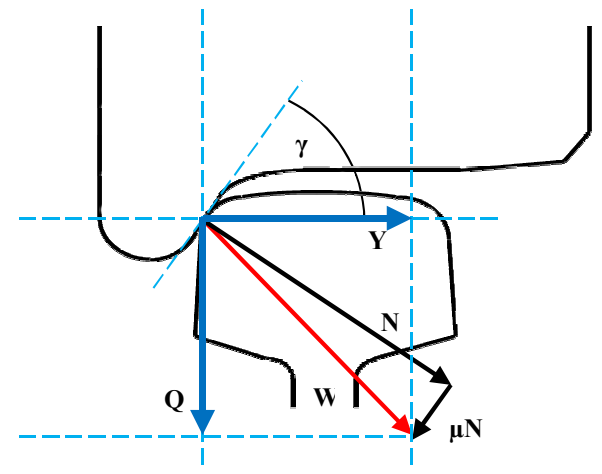

Rys. 2.1. Rozkład sił w jednopunktowym styku koła z szyną. Objaśnienia oznaczeń w tekście.

Na rys. 2.1. przedstawiono prawe koło zestawu kołowego (1 na rys. 2.1.), poruszające się po szynie zewnętrznej łuku lewego bez przechyłki ( 2 na rys. 2.1.). Symbolem $\gamma$ oznaczono kąt pochylenia obrzeża koła względem osi poziomej. Prostopadle do obrzeża została poprowadzona siła normalna, na rys. 2.1. oznaczona jako N. Prostopadle do niej działa siła tarcia, stanowiąca iloczyn współczynnika tarcia pomiędzy materiałem koła i szyny (na rys 2.1. oznaczony jako $\mu$ ) oraz wartości siły normalnej. Po złożeniu wektorów obu sił otrzymuje się wektor siły wypadkowej, oznaczony jako W. Rzutując siłę wypadkową na oś poziomą i pionową otrzymuje się odpowiednio: siłę prowadzącą Y oraz siłę pionowego nacisku Q. Ich stosunek stanowi podstawowy parametr charakteryzujący bezpieczeństwo przed wykolejeniem danego pojazdu. Po uwzględnieniu zależności geometrycznych z rys. 2.1. otrzymuje się następujący wzór:

$$
\left(\frac{Y}{Q}\right)_{\text {nieb }}=\frac{N \cdot \sin \gamma-\mu N \cdot \cos \gamma}{N \cdot \cos \gamma+\mu N \cdot \sin \gamma}
$$

Przekształcając wzór (1) oraz redukując wyrazy podobne otrzymuje się zależność:

$$
\left(\frac{Y}{Q}\right)_{\text {nieb }}=\frac{\operatorname{tg} \gamma-\mu}{1+\mu \cdot \operatorname{tg} \gamma}
$$

Otrzymany stosunek siły prowadzącej do siły nacisku pionowego, wyrażony wzorem (2) stanowi kryterium bezpieczeństwa przed wykolejeniem. Jego przekroczenie skutkuje zwiększonym prawdopodobieństwem zejścia zestawu kołowego z szyny i w rezultacie wykolejeniem pojazdu. Rzeczywisty stosunek sił prowadzących do siły pionowego nacisku może zostać otrzymany w wyniku przeprowadzenia znormalizowanych badań danego pojazdu lub obliczeniowe wyznaczenie na podstawie danych konstrukcyjnych. Metody te zostana przedstawione w 4 . oraz 5 . rozdziale niniejszego artykułu.

\section{Wymagania normatywne badań współ- czynnika przed wykolejeniem}

\subsection{Norma PN-EN 14363:2007}

Jak wynika ze wzoru (2) wartość obliczeniowego współczynnika bezpieczeństwa przed wykolejeniem zależy bezpośrednio od współczynnika tarcia pomiędzy kołem i szyną oraz od kąta pochylenia obrzeża koła. Dla współczynnika tarcia równego 0,36 (wartość określona w normie [4]) oraz obecnie stosowanego kąta pochylenia obrzeża $70^{\circ}$ dla kół nowych otrzymuje się współczynnik bezpieczeństwa przed wykolejeniem równy:

- 0,8 - dla jazdy po torze prostym w normalnych warunkach jazdy i dla łuków toru o promieniu min. $300 \mathrm{~m}$,

- 1,2 - dla jazdy po torze wichrowatym w warunkach quasistatycznych, przy stałej prędkości jazdy, nieprzekraczającej $10 \mathrm{~km} / \mathrm{h}$ i dla łuku toru o promieniu $150 \mathrm{~m}$.

Współczynnik $\mathrm{Y} / \mathrm{Q}=0,8$ dla łuków torów o promieniu R ? $300 \mathrm{~m}$ przyjęto na podstawie pomiarów zużycia główki szyny na torach europejskich. $\mathrm{W}$ ten sposób określono średni poziom zużycia dla całego kontynentu europejskiego i na jego podstawie wyznaczono przytoczony współczynnik, który zapewnia odpowiedni poziom bezpieczeństwa dla przejeżdżających wagonów towarowych i przyjęto go za obowiązujący w normie europejskiej [4].

Norma [4] określa trzy główne metody eksperymentalnego wyznaczania współczynnika bezpieczeństwa przed wykolejeniem: przejazd przez tor $z$ odcinkiem zwichrowanym, przejazd przez tor bez wichrowatości oraz pomiar wichrowania kół na stanowisku badawczym.

Pierwszą z metod wyznaczania wartości stosunku Y/Q jest przejazd przez tor badawczy z określoną wichrowatością. W normie [4] określono wymagania, jakie musi spełniać odcinek toru, na którym będą przeprowadzane przejazdy badawcze. Tor powinien odzwierciedlać normalne warunki typowego toru 
uwzględniając zarys szyny, szerokość i stan utrzymania. Łuk toru musi mieć stały promień $\mathrm{R}=150 \mathrm{~m}$. Na łuku powinien znajdować się odcinek zwichrowany o wichrowatości $3 \%$, położony na fragmencie toru ze stałym promieniem łuku. Wichrowatość powinna być zrealizowana poprzez zmianę wysokości położenia zewnętrznej szyny. Przykładowy tor badawczy z odcinkiem wichrowatym, zgodny $\mathrm{z}$ normą [4] przedstawiono na rys. 3.1 .

a)

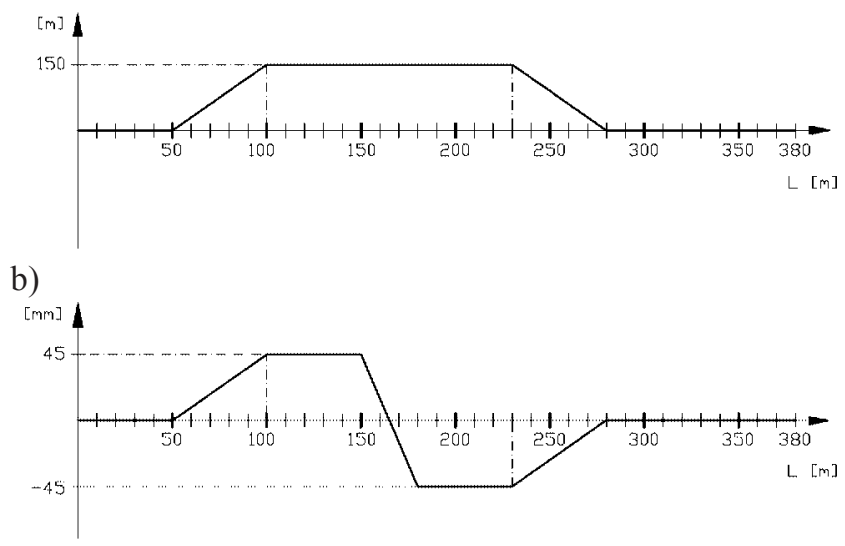

Rys. 3.1. Przebieg przykładowego toru badawczego z odcinkiem wichrowatym o stałej wichrowatości $3 \%$.

a) promień łuku toru w funkcji długości toru badawczego

b) przechyłka toru w funkcji długości toru badawczego

$\mathrm{Na}$ rys 3.1. odcinek o stałej wichrowatości znajduje się pomiędzy 150 a 180 metrem toru. Badania współczynnika Y/Q należy przeprowadzać w suchych warunkach pogodowych aby uwzględnić najwyższy możliwy współczynnik tarcia na styku pary koło-szyna. Pojazd powinien być badany w stanie próżnym dla jak najmniejszych nacisków pionowych. Przejazd powinien się odbywać ze stałą prędkością, nie wyższą niż $10 \mathrm{~km} / \mathrm{h}$ w celu minimalizowania siły wzdłużnej. W przypadku pojazdu trakcyjnego powinien on być przetaczany nie korzystając $\mathrm{z}$ własnego napędu.

Przejazd przez tor wichrowaty powinien zostać wykonany przynajmniej 3 razy. W przypadku przekroczenia maksymalnego dopuszczalnego współczynnika $(\mathrm{Y} / \mathrm{Q})_{\mathrm{obl}}=1,2$ przy jednoczesnym pozostaniu koła na szynie podczas każdego z przejazdów, powinno się dokonać pomiaru uniesienia koła. Gdy zmierzona wartość jest niższa od $5 \mathrm{~mm}$ to warunkowo uznaje się, że pojazd przeszedł badania ze skutkiem pozytywnym. Dla takiego przypadku należy dodatkowo dokonać pomiaru kąta zarysu zewnętrznego obrzeża, który w każdym miejscu na zarysie nie powinien przekraczać $70^{\circ}$. Zmierzony zarys koła dołącza się do raportu z badań. Ponownie należy sprawdzić czy na profilu koła i szyn nie znajdują się pozostałości smaru lub wilgoć. Badanie po przekroczeniu dopuszczalnego Y/Q daje wynik pozytywny gdy podczas 3 przejazdów zostały zachowane powyższe ograniczenia.

\subsection{Techniczne specyfikacje interoperacyjności}

Techniczne specyfikacje interoperacyjności (TSI) nie wprowadzają nowych kryteriów bezpieczeństwa przed wykolejeniem. Wszystkie przywołane w nich wartości mają swoje odzwierciedlenie w europejskiej normie PN-EN 14363:2007. TSI [8, 9, 10] ogólnie przedstawiają kryterium Prudhomme'a (opisane w rozdziale 4) jako graniczną siłę poprzeczną $\mathrm{Y}$ oraz wartości graniczne stosunku Y/Q w zależności od promienia łuku toru, odpowiednio 0,8 dla łuków R ? $250 \mathrm{~m}$ i 1,2 dla łuków $\mathrm{R}<250 \mathrm{~m}$.

TSI dla kolei dużych prędkości [8] dodatkowo podaje dopuszczalne parametry profilu koła, które muszą być spełnione dla zachowania odpowiedniego poziomu bezpieczeństwa przed wykolejeniem:

- kąt pochylenia obrzeża ( $\gamma$ na rys. 2.1.) powinien wynosić co najmniej $67^{\circ}$

- kąt powierzchni stożkowej profilów kół powinien zawierać się w zakresie $3,7 \div 8,5^{\circ}$

- stożkowatość ekwiwalentna powinna przyjmować wartości ujęte w tabeli 3.1.

Graniczne wartości stożkowatości ekwiwalentnej dla pojazdów dużych prędkości [8]

Tabela 3.1.

\begin{tabular}{|c|c|}
\hline $\begin{array}{c}\mathbf{V}_{\text {max }} \text { pojazdu } \\
{[\mathrm{km} / \mathrm{h}]}\end{array}$ & $\begin{array}{c}\text { Graniczna wartość } \\
\text { stożkowatości ekwiwa- } \\
\text { lentnej }[-]\end{array}$ \\
\hline $190 \leq \mathrm{V}_{\max } \leq 230$ & 0,25 \\
\hline $230<\mathrm{V}_{\max } \leq 280$ & 0,20 \\
\hline $280 \leq \mathrm{V}_{\max } \leq 300$ & 0,10 \\
\hline $\mathrm{V}_{\max }>300$ & 0,10 \\
\hline
\end{tabular}

\section{Obliczenia teoretyczne współczynnika bez- pieczeństwa przed wykolejeniem}

Graniczna dopuszczalna wichrowatość pojaz$\mathrm{du} \mathrm{g}^{*}{ }_{\lim } \mathrm{W}$ odniesieniu do rozstawu osi obrotu wózków wagonu (lub rozstawu osi wagonu dwuosiowego) $2 \mathrm{a}^{*}$ wynosi:

$$
\begin{array}{lr}
g_{\lim }^{*}=7-\frac{5}{2 a^{*}} \text { dla } & 2 \mathrm{a}^{*}<4 \mathrm{~m} ; \\
g_{\lim }^{*}=\frac{15}{2 a^{*}}+2 & \text { dla } 4 \mathrm{~m} \leq 2 \mathrm{a}^{*} \leq 20 \mathrm{~m} ; \\
g_{\lim }^{*}=3-\frac{5}{2 a^{*}} & \text { dla } 20 \mathrm{~m} \leq 2 \mathrm{a}^{*} \leq 30 \mathrm{~m} ; \\
g_{\lim }^{*}=\frac{85}{2 a^{*}} & \text { dla } 2 \mathrm{a}^{*}>30 \mathrm{~m} ;
\end{array}
$$

Graniczna dopuszczalna wichrowatość pojaz-

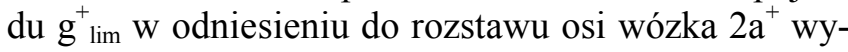
nosi: 


$$
\begin{array}{ll}
g_{\text {lim }}^{+}=7-\frac{5}{2 a^{+}} & \text {dla } 2 \mathrm{a}^{+}<4 \mathrm{~m} ; \\
g_{\text {lim }}^{+}=\frac{15}{2 a^{+}}+2 & \text { dla } 2 \mathrm{a}^{+} \geq 4 \mathrm{~m} ;
\end{array}
$$

Wskutek istnienia luzów na ślizgach bocznych sztywnych $d_{\mathrm{ZGII}}, d_{\mathrm{ZGI} 2}, d_{\mathrm{ZGII}}, d_{\mathrm{ZGII}}$ zmniejsza się wichrowatość w odniesieniu do bazy pojazdu g*. Ilościowo wyraża się ją wzorem:

$$
g_{G}=\frac{2 b_{A}}{b_{G}} \cdot \frac{d_{Z G I 1}+d_{Z G I 2}+d_{Z G I I 1}+d_{Z G I I 2}}{2 \cdot 2 a^{*}}
$$

gdzie:

$2 b_{\mathrm{A}} \quad$ - rozstaw okręgów tocznych [mm];

$\mathrm{b}_{\mathrm{G}} \quad$ - odległość osi pojedynczego ślizgu bocznego od osi wzdłużnej wózka [mm]

$\mathrm{d}_{\mathrm{ZGII}}, \mathrm{d}_{\mathrm{ZGI} 2}, \mathrm{~d}_{\mathrm{ZGIII}}, \mathrm{d}_{\mathrm{ZGII} 2}$ - luzy na ślizgach bocznych na wózku I oraz II [mm]

Wzór (9) obowiązuje dla ślizgów bocznych sztywnych. Dla wózków ze ślizgami bocznymi sprężystymi zmniejszenie wichrowatości oblicza się $\mathrm{w}$ odmienny sposób, który zostanie przedstawiony $\mathrm{w}$ kolejnych publikacjach. Przekrój przykładowego wózka ze ślizgami bocznymi sztywnymi przedstawiono na rys. 4.1 .

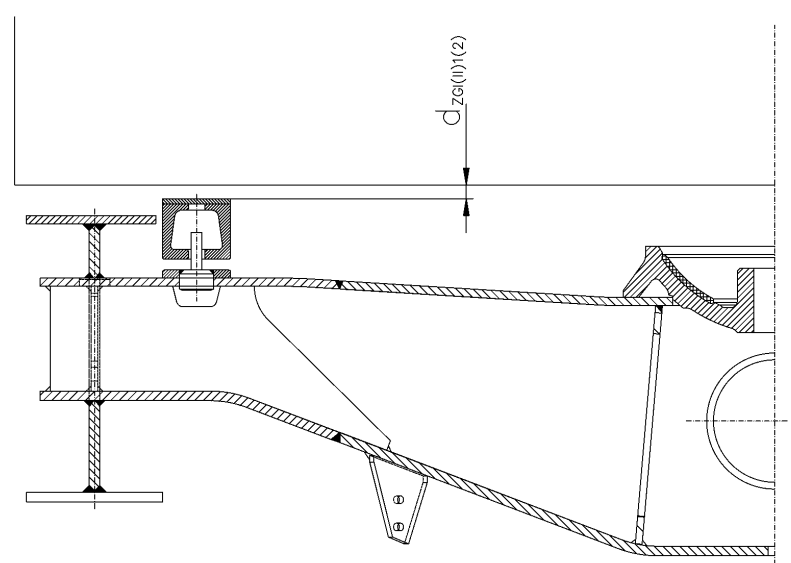

Rys. 4.1. Przekrój poprzeczny wózka ze ślizgami bocznymi sztywnymi.

Całkowita wichrowatość pojazdu ma wpływ na odciążenie koła prowadzącego. Wyraża się je następująco:

$$
\Delta Q_{r z e c z}=\left(g^{*}-g_{G}\right) \cdot c_{t A\left(2 a^{*}\right)}+g^{+} \cdot c_{t A\left(2 a^{+}\right)}
$$

gdzie:

$\mathrm{Q}_{0} \quad$ - statyczny nacisk pojedynczego koła na szynę na torach prostych bez przechyłki $[\mathrm{kN}]$

$\mathrm{k}=1 \quad-$ dla lokomotyw, zespołów trakcyjnych, wagonów silnikowych i osobowych;

$\mathrm{k}=0,85-$ dla wagonów towarowych [2].

Wzór (11) nazywany jest kryterium Prudhomme'a. Za jego pomocą wyznacza się graniczną wartość siły poprzecznej, działającej na tor, którą należy przyłożyć do toru $\mathrm{z}$ równoczesnym jego pionowym obciążeniem siłą $2 \mathrm{Q}_{0}$ aby dokonać jego trwałej deformacji poprzecznej. Współczynnik $\mathrm{k}=$ 0,85 został przyjęty dla wagonów towarowych z racji dużego rozrzutu wymiarów geometrycznych toru, po którym poruszaja się pociagi towarowe. Założono gorszy stan utrzymania linii, po których poruszają się pociagi prowadzące wagony towarowe.

\section{Doświadczalne wyznaczanie stosunku Y/Q 5.1. Wyznaczanie stosunku $Y / Q$ na badawczym torze wichrowatym}

Jedną z metod pomiaru współczynnika bezpieczeństwa przed wykolejeniem jest przejazd przez tor ze znormalizowanym odcinkiem wichrowatym. Wymagania normy [4] podano wcześniej, a przykładowy przebieg toru przedstawiono na rys. 3.1.

W Polsce jednym $z$ ośrodków, mających do dyspozycji tor wichrowaty jest Instytut Pojazdów Szynowych „Tabor” w Poznaniu. Na rys. 5.1. przedstawiono tor $\mathrm{z}$ odcinkiem wichrowatym, znajdujący się na terenie Instytutu.

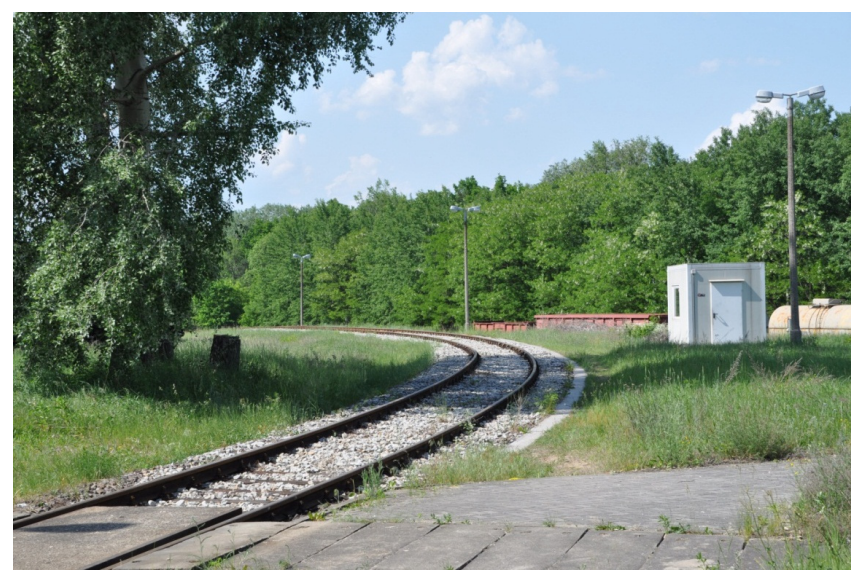

Rys. 5.1. Badawczy tor wichrowaty Instytutu Pojazdów Szynowych „Tabor” w Poznaniu.

$\mathrm{Z}$ obu stron toru do szyn, pomiędzy podkładami, przymocowano układ tensometrów, generujących sygnały elektryczne wywołane odkształceniami pionowymi i poprzecznymi. Cały układ chroniony jest przed uszkodzeniami mechanicznymi (np. wskutek wykolejenia się pojazdu) metalową osłoną z wyprowadzonym gniazdem na jednej ze ścian. Do gniazda przyłącza się kable, prowadzące do przetwornika pomiarowego, zbierającego sygnały ze wszystkich układów tensometrycznych. Fragment toru badawczego z układami tensometrów w metalowych osłonach został przedstawiony na rys. 5.2.

$\mathrm{Na}$ podstawie sygnału elektrycznego z układu tensometrów, zbieranych przez przetwornik pomiarowy, w programie komputerowym wyznaczane są siły prowadzące oraz siły pionowego nacisku dla prawego i lewego koła prowadzącego zestawu kołowego. Ich stosunek stanowi współczynnik bezpieczeństwa przed 
wykolejeniem. Jego przebieg jest rejestrowany równocześnie z pozycją pojazdu na torze badawczym.

Norma [4] wymaga również pomiaru uniesienia koła prowadzącego pierwszego zestawu kołowego badanego pojazdu. Czynność tą realizuje się poprzez montaż specjalnego wspornika do maźnicy zestawu kołowego, do którego z kolei przykręca się przetworniki pomiarowe. Widok układu, służącego do pomiaru uniesienia koła został przedstawiony na rys. 5.3.

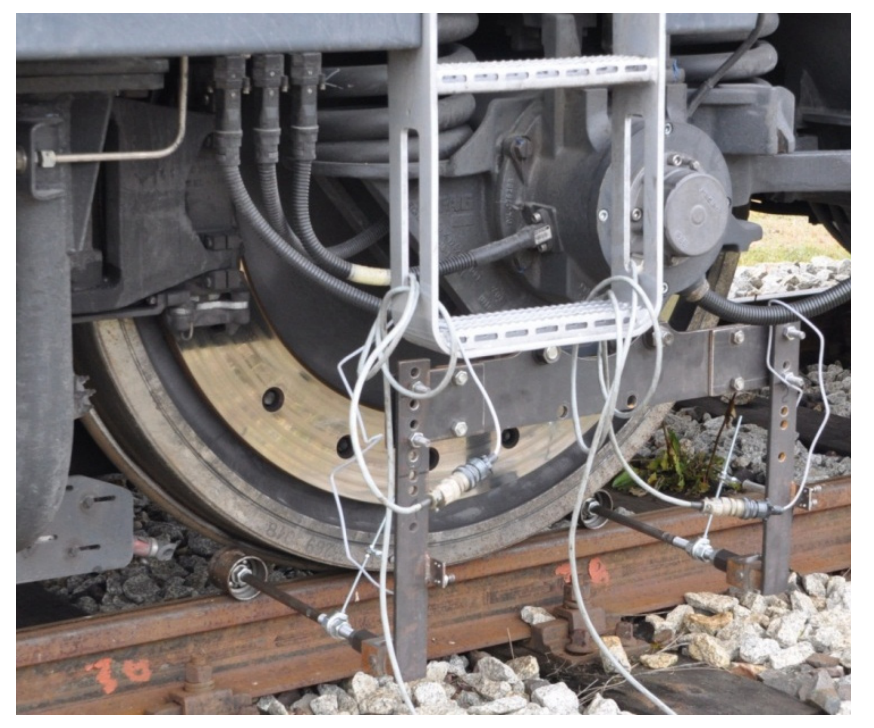

Rys. 5.3. Układ do pomiaru uniesienia koła prowadzącego badanego pojazdu szynowego.

Uniesienie koła prowadzącego powoduje jednoczesne uniesienie maźnicy z przymocowanym do niej mechanizmem pomiarowym. Ruch wspornika powoduje obniżenie położenia pręta $\mathrm{z}$ rolką prowadząca, połączonego $\mathrm{z}$ mechanizmem pomiarowym przegubowo. Rolka podczas ruchu pojazdu cały czas toczy się po szynie. Ruch pręta z rolką powoduje ruch tłoczka w urządzeniu pomiarowym, co generuje impuls elektryczny, odbierany przez przetwornik pomiarowy. Sygnał po przetworzeniu jest zamieniany na informację o zmianie położenia koła względem szyny. $\mathrm{Z}$ racji różnych odległości pomiędzy maźnicą na główką szyny dla różnych pojazdów szynowych przed rozpoczęciem pomiarów uniesienia koła wymagana jest kalibracja zastosowanych urządzeń pomiarowych.

\subsection{Wyznaczanie stosunku $Y / Q$ na stanowisku do badania wichrowania i na torze badaw- czym bez przechyłki}

Wymaga się aby stanowisko badawcze do wichrowania miało podparcie minimum dwóch zestawów kołowych jednego wózka i umożliwiało ich podnoszenie i opuszczanie. $\mathrm{W}$ ten sposób symulowane jest wichrowanie wagonu jednocześnie na bazie wózka i bazie wagonu, zgodnie ze wzorami $(3 \div 8)$. Po osiagnięciu wymaganej wichrowatości dokonuje się pomiaru sił pionowego nacisku dla wszystkich kół. Następnie pojazd kierowany jest na tor badawczy. Tor posiada odcinek prosty i łuk o stałym promieniu $\mathrm{R}=150 \mathrm{~m}$. Na torze nie stosuje się krzywych przejściowych i przechyłki. Wagon należy ustawić w torze tak, aby koło skrajnego zestawu o najmniejszym nacisku pionowym znajdowało się na szynie zewnętrznej i było kołem prowadzącym. Warunki badań i utrzymania toru sa identyczne jak dla przypadku toru badawczego z wichrowatością. Podczas przejazdu mierzy się siły prowadzące na obu kołach prowadzącego zestawu kołowego, siłę pionowego nacisku wewnętrznego koła zestawu prowadzącego oraz kąt nabiegania zestawu prowadzącego.

Po dokonaniu pomiarów, otrzymane wartości podstawia się do wzorów (12) oraz (13):

$$
\begin{aligned}
\left(\frac{Y}{Q}\right)_{j a} & =\frac{Y_{j a, \text { med }}}{Q_{j k, \min }+\Delta Q_{j H}} \\
\Delta Q_{j H} & =\left(Y_{j a}+Y_{j i}\right) \frac{h}{2 b_{A}}
\end{aligned}
$$

Wartość otrzymanego ilorazu porównuje się z wartością graniczną, przedstawioną w rozdziale 3.1 niniejszego artykułu.

\subsection{Ocena bezpieczeństwa przed wykolejeniem na stanowisku do badania wichrowania i na stanowisku do pomiaru skrętu wózków}

Metoda oceny bezpieczeństwa na stanowisku do wichrowania może służyć wyłącznie do badań pojazdów o konwencjonalnej technologii, posiadających dwa wózki dwuosiowe $\mathrm{z}$ osiami o profilu charakteryzującym się kątem pochylenia obrzeży kół w zakresie $68^{\circ} \div 70^{\circ}$. Do obliczeń przyjmuje się nieco inne wartości wichrowatości granicznych niż przedstawione uprzednio. Graniczna wichrowatość dla wózków $\mathrm{g}^{+}{ }^{+}$ wynosi:

$$
\begin{array}{ll}
g_{\lim }^{+}=7 \% \text { dla } 2 \mathrm{a}^{+}<5 \mathrm{~m} \\
g_{\lim }^{+}=\frac{20}{2 a^{+}}+3 & \text { dla } 2 \mathrm{a}^{+} \geq 5 \mathrm{~m}
\end{array}
$$

Graniczna wichrowatość dla nadwozia pojazdu wyraża się następująco:

$$
g_{\lim }^{*}=\frac{20}{2 a^{*}}+3
$$

Badanie łącznego wichrowania wózka i nadwozia pojazdu należy wykonywać na urządzeniu, umożliwiającym podnoszenie i opuszczanie minimum dwóch osi jednego wózka pojazdu. Podczas badań mierzy się przemieszczenia oraz siły pionowego nacisku poszczególnych kół pojazdu. $\mathrm{Na}$ odpowiednim stanowisku dokonuje się również pomiaru momentu obrotowego wózka.

Istotą opisywanej metody badawczej jest wyznaczenie stosunku odciążenia koła prowadzącego do 
siły pionowego nacisku przy braku wichrowatości oraz współczynnika X, charakteryzującego zachowanie się wózka na łukach o małym promieniu. Graniczne wielkości, określone normą [4] zostały przedstawione poprzez wzory (17) i (18):

$$
\begin{aligned}
& \frac{\Delta Q}{Q_{0}} \leq 0,6 \\
& X=\frac{M_{z, R \min }}{2 a^{+} \cdot 2 Q_{0}} \leq 0,1
\end{aligned}
$$

gdzie:

$\mathrm{Q}_{0}$ - siła pionowego nacisku pojedynczego koła na szynę na torze płaskim i prostym;

$\Delta \mathrm{Q}$ - odchyłka od wartości $\mathrm{Q}_{0}$ dla warunków maksymalnej wichrowatości pojazdu;

$\mathrm{M}_{\mathrm{z}, \mathrm{Rmin}}$ - moment potrzebny do obrotu wózka względem nadwozia o kąt $\varphi$.

Kąt $\varphi$ dla danego pojazdu oblicza się według zależności (19):

$$
\varphi=\frac{a^{*}}{R_{\min }}
$$

gdzie:

$\mathrm{a}^{*} \quad-1 / 2$ wartości bazy pojazdu $2 \mathrm{a}^{*}[\mathrm{~m}]$;

$\mathrm{R}_{\min } \quad-$ minimalny promień łuku, możliwy do przejechania przez dany pojazd [m].

Kąt $\varphi$ jest wyrażony $w$ radianach. Zależność dla współczynnika $X$, określona wzorem (18) obowiązuje dla wszystkich pojazdów pasażerskich oraz lokomotyw. Dla pojazdów towarowych współczynnik X powinien być mniejszy od wartości granicznej, przedstawionej na wykresie na rys. 5.4.

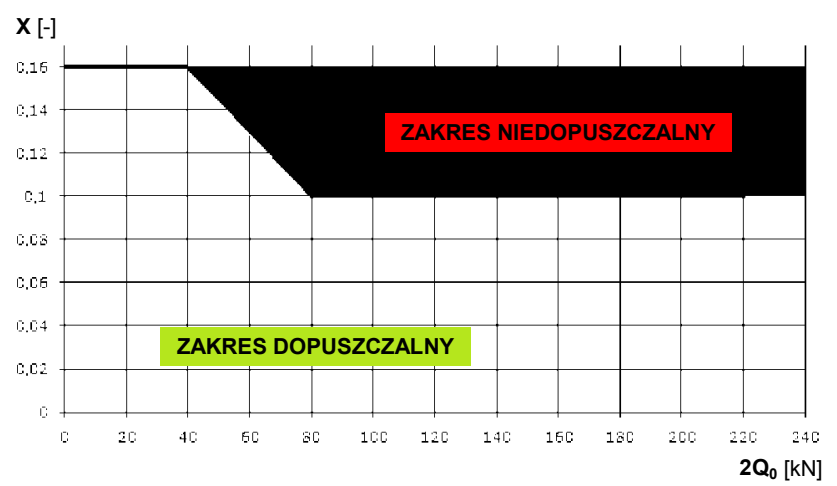

Rys. 5.4. Graniczna wartość współczynnika X dla pojazdów towarowych w zależności od nacisku osi na tor. [4]

\section{Wpływ kąta nabiegania na współczynnik Y/Q}

Dla wagonu (lub wózka) 2-osiowego występuje 5 przypadków położenia zestawów kołowych w łuku toru:
1) położenie narożnikowe: oś prowadząca nabiega na szynę zewnętrzną łuku, a oś tylna nabiega na szynę wewnętrzną. Dla obu osi został wyczerpany luz poprzeczny q (na stronę). Położenie narożnikowe przedstawiono na rys. 6.1 .

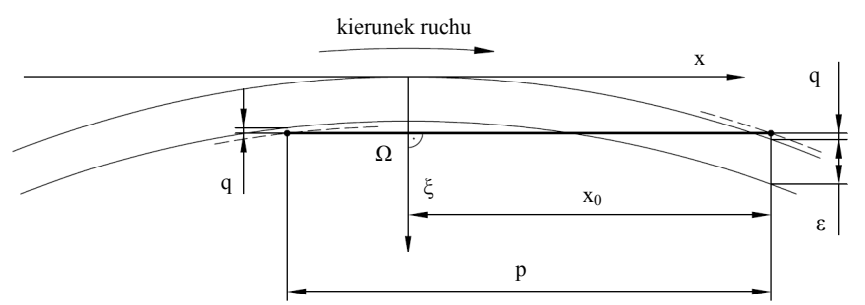

Rys. 6.1. Położenie narożnikowe wagonu po wyczerpaniu przesuwu osi skrajnych.

2) położenie $z$ tyłu swobodne: oś prowadząca nabiega na szynę zewnętrzną łuku $z$ wyczerpaniem luzu poprzecznego q, a tylna oś znajduje się w położeniu swobodnym. Położenie $\mathrm{z}$ tyłu swobodne zostało przedstawione na rys. 6.2 .

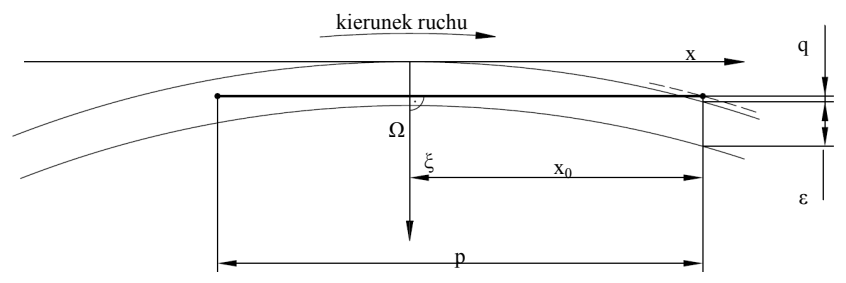

Rys. 6.2. Położenie z tyłu swobodne wagonu po wyczerpaniu przesuwu osi przedniej.

3) położenie z przodu swobodne: oś prowadząca znajduje się w położeniu swobodnym, a tylna oś nabiega na szynę zewnętrzną. Położenie $\mathrm{z}$ przodu swobodne zostało przedstawione na rys. 6.3 .

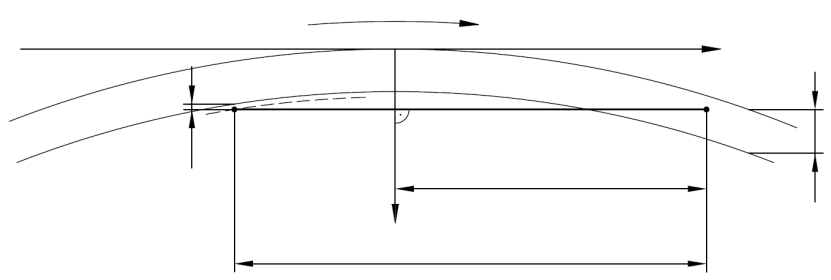

Rys. 6.3. Położenie z przodu swobodne wagonu po wyczerpaniu przesuwu osi tylnej.

4) położenie skrajne zewnętrzne: obie osie wagonu nabiegają na szynę zewnętrzną łuku. Położenie skrajne zewnętrzne zostało przedstawione na rys. 6.4. 


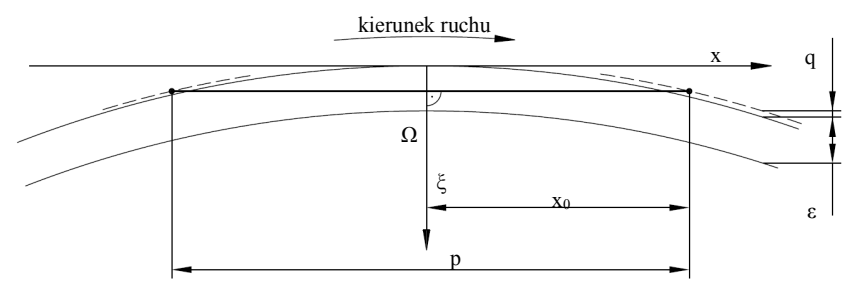

Rys. 6.4. Położenie skrajne zewnętrzne wagonu po wyczerpaniu przesuwu obu osi.

5) położenie skrajne wewnętrzne: obie osie wagonu lub wózka nabiegają na szynę wewnętrzną. Położenie skrajne wewnętrzne zostało przedstawione na rys. 6.5.:

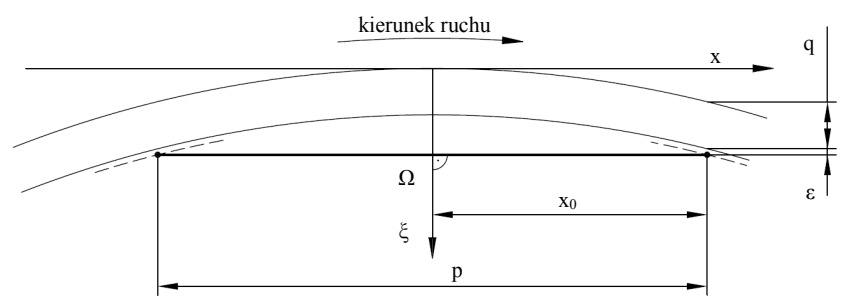

Rys. 6.5. Położenie skrajne wewnętrzne wagonu po wyczerpaniu przesuwu obu osi.

$\mathrm{x}_{0} \quad-\quad$ odstęp biegunowy (bieguna $\Omega$ ) względem przedniej osi prowadzącej wagonu; $\mathrm{R} \quad-\quad$ promień łuku toru; q $\quad-\quad$ przesuw poprzeczny osi zestawu kołowego względem wideł maźniczych; $\varepsilon \quad-\quad$ luz zestawu kołowego w torze; p _ - baza wagonu.

Dalsze przekształcenia opierają się następujących założeniach [3]:

- łuki kołowe szyny zewnętrznej i wewnętrznej zastępuje się dwiema identycznymi parabolami przesuniętymi względem siebie wzdłuż osi $\xi$,

- luz zestawu kołowego w torze, oraz położenia i przemieszczenia danych punktów wagonu względem szyn mierzy się w kierunku równoległym do osi $\xi$ (nie w kierunku promieniowym).

Na podstawie rys. 6.1. można wyprowadzić równanie:

$$
\frac{x_{0}^{2}}{2 R}-q=\frac{\left(p-x_{0}\right)^{2}}{2 R}+\varepsilon+q
$$

Przekształcając wzór otrzymuje się:

$$
x_{0}^{2}-2 R q=p^{2}-2 p x_{0}+x_{0}^{2}+2 R(\varepsilon+q)
$$

Na podstawie równania (21) wyznacza się odstęp biegunowy $\mathrm{x}_{0}$ :

$$
x_{0}=\frac{R(\varepsilon+2 q)}{p}+\frac{p}{2}
$$

Wzór (22) jest ważny dla położenia narożnikowego pojazdu szynowego w huku toru. Dla pozostałych rodzajów ustawień w łuku wzór należy odpowiednio zmodyfikować.

W przypadku położenia z przodu (lub z tyłu) swobodnego, poprzeczny luz zestawu kołowego będzie stanowił sumę wartości luzu zestawu kołowego w torze oraz przesuwu poprzecznego przedniego (lub tylnego) zestawu kołowego. Wzór na wyznaczenie odstępu biegunowego $\mathrm{x}_{0}$ dla takiego położenia (w obu przypadkach) wygląda następująco:

$$
x_{0}=\frac{R(\varepsilon+q)}{p}+\frac{p}{2}
$$

Jako najniekorzystniejszy przypadek należy przyjąć położenie narożnikowe pojazdu szynowego w łuku toru, dla którego odstęp biegunowy $\mathrm{x}_{0}$ jest największy.

$\mathrm{Z}$ racji istnienia luzów w elementach prowadzenia widłowego zestawu kołowego lub podatności pozostałych typów prowadzeń koło nabiega na szynę w łuku pod określonym kątem. Kąty nabiegania kół zestawów kołowych pojazdu szynowego na łuku dla położenia narożnikowego przedstawiono na rys. 6.6.

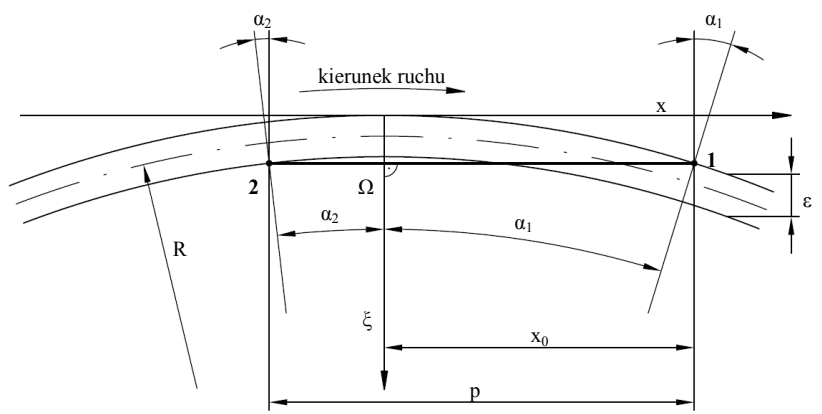

Rys. 6.6. Kąty nabiegania kół zestawów kołowych pojazdu szynowego dla położenia narożnikowego. Opracowano na podstawie [3]

$\mathrm{Na}$ podstawie rys. 6.6. można wyprowadzić następujące zależności dla kątów nabiegania $\alpha_{1}$ oraz $\alpha_{2}$ :

$$
\begin{aligned}
& \sin \alpha_{1}=\frac{x_{0}}{R+\frac{\varepsilon}{2}} \\
& \sin \alpha_{2}=\frac{x_{0}-p}{R-\frac{\varepsilon}{2}}
\end{aligned}
$$

Największy kąt nabiegania występuje dla pierwszej osi pojazdu szynowego i dla tej osi występuje również największa wartość stosunku siły prowadzącej do nacisku (Y/Q), co zostało potwierdzone m.in. w badaniach symulacyjnych np. [1], zatem zasadne jest rozpatrywanie kąta nabiegania dla tego przypadku. 
W przypadku gdy zestaw kołowy posiada możliwość przesuwu wzdłużnego ( $\mathrm{w}$ wyniku luzów lub podatności prowadzenia zestawu) kąt nabiegania zmniejsza się o wartość $\Delta \alpha \mathrm{w}$ wyniku quasiradialnego ustawiania się zestawu kołowego w torze, wyrażoną następującym wzorem:

$$
\Delta \alpha=\operatorname{arctg} \frac{q_{w}}{s}
$$

gdzie:

$\mathrm{q}_{\mathrm{w}} \quad-\quad$ wielkość wzdłużnych luzów przymaźnicznych zestawu kołowego [mm]

2s - odległość pomiędzy zewnętrznymi powierzchniami korpusów prowadnic $[\mathrm{mm}]$

Dla małych kątów $\alpha \leq 10^{\circ}$ różnica pomiędzy wartością kąta $\alpha$ a wyrażeniem $\sin \alpha$ jest nie większa niż $0,5 \%$, zatem z wystarczającą dokładnością można zapisać:

$$
\sin \alpha \cong \alpha
$$

Ostateczny wzór na kąt nabiegania koła na szynę $\alpha_{1}$ po uwzględnieniu zmniejszenia jego wartości $\mathrm{w}$ wyniku quasiradialnego ustawiania się zestawu $\mathrm{w}$ łuku toru wygląda następująco:

$$
\alpha_{1}{ }^{\prime}=\alpha_{1}-\Delta \alpha=\frac{x_{0}}{R+\frac{\varepsilon}{2}}-\frac{q_{w}}{s}
$$

Widok nabiegania koła na szynę w łuku toru został przedstawiony na rys. 6.7.

Płaszczyzna przecinająca $\mathrm{w}$ poziomie punkt $\mathrm{B}$ wyznacza przekrój stożka, którego wierzchołek znajduje się na osi zestawu kołowego, a tworzące tego stożka są wyznaczone powierzchnią obrzeża i nachylone pod kątem $\gamma$ do osi zestawu. Obrys wspomnianego przekroju jest hiperbolą o następującym równaniu:

gdzie:

$$
\frac{v^{2}}{v_{0}^{2}}-\frac{u^{2}}{u_{0}^{2}}=1
$$

$$
u_{0}=\gamma_{0} \cdot \operatorname{tg} \gamma
$$

po przekształceniu:

$$
\frac{v_{0}}{u_{0}}=\frac{1}{\operatorname{tg} \gamma}
$$

Po różniczkowaniu równanie (29) przyjmuje następującą postać:

$$
\frac{2 v d v}{v_{0}^{2}}-\frac{2 u d u}{u_{0}^{2}}=0
$$

Przekształcając dalej:

$$
\frac{d v}{d u}=\frac{u}{u_{0}^{2}} \cdot \frac{v_{0}^{2}}{v}=\frac{v_{0}^{2}}{u_{0}^{2}} \cdot \frac{u}{v}
$$

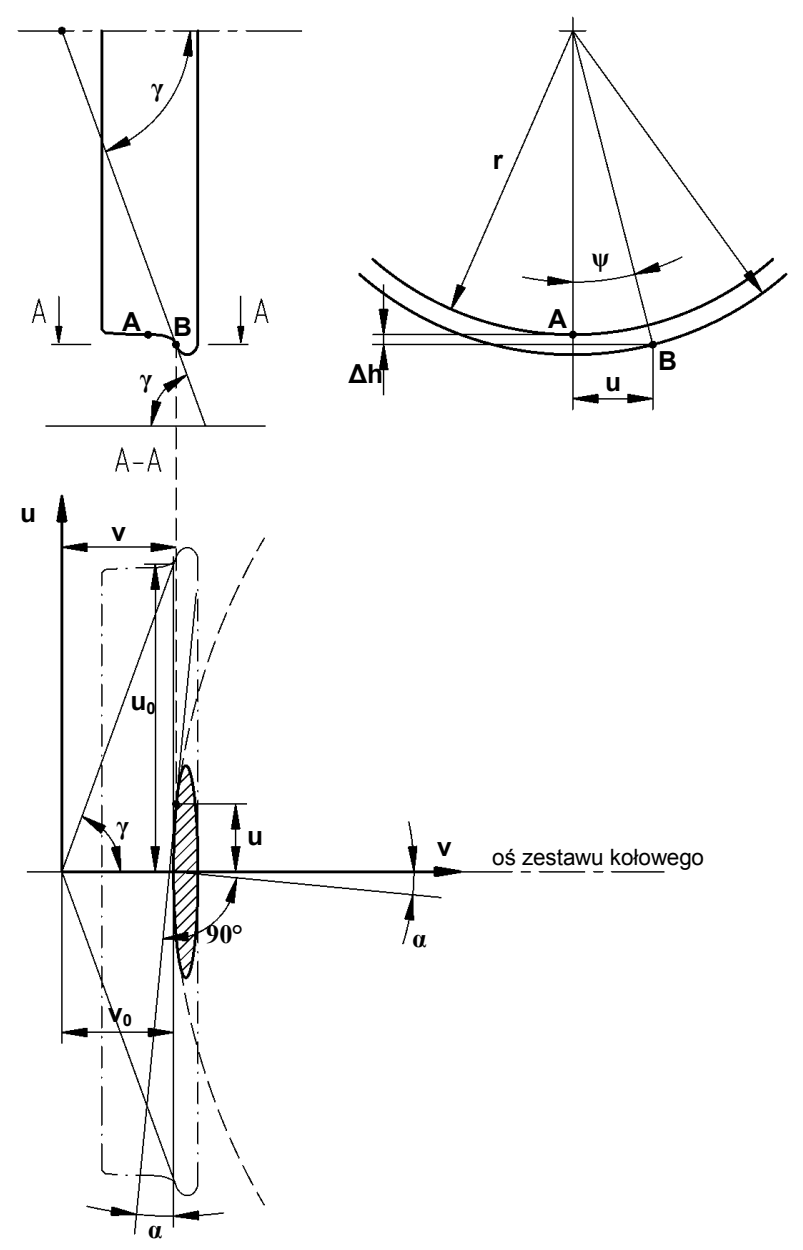

Rys. 6.7. Nabieganie koła na szynę w łuku toru.

Wyrażenie $\frac{d v}{d u}$ stanowi tangens kąta nachylenia stycznej do hiperboli względem osi u. Uwzględniając powyższą informację oraz wyrażenie (31) równanie (33) przyjmuje postać:

$$
\operatorname{tg} \alpha=\frac{1}{\operatorname{tg}^{2} \gamma} \cdot \frac{u}{v}
$$

Zgodnie $\mathrm{z}$ rys. 6.7. współrzędne punktu B to $(\mathrm{v} ; \mathrm{u})$, przy czym:

$$
\begin{aligned}
& v=\frac{r^{\prime}}{\operatorname{tg} \gamma} \\
& u=r^{\prime} \cdot \sin \psi
\end{aligned}
$$

Uwzględniając (34), (35) oraz (36) otrzymuje się następującą zależność:

$$
\sin \psi=\operatorname{tg} \alpha \cdot \operatorname{tg} \gamma
$$

Znając kąt $\psi$ oraz wartość wielkości $\Delta$ h można wyznaczyć wyprzedzanie nabiegania, oznaczone jako „u” na rys. 6.7. Wartość wielkości $\Delta \mathrm{h}$ jest stała dla danego typu obrzeża.

Celem tych przekształceń jest przedstawienie wpływu kąta nabiegania zestawu kołowego na szynę w łuku toru na stosunek siły prowadzącej do siły pionowego nacisku. Na rys. 6.8. przedstawiono położenie punktów styku podczas nabiegania koła na szynę oraz rozkład sił w punkcie styku obrzeża i szyny. 
Na rys. 6.8. założono, że siła prowadząca Y na przekroju B-B działa równolegle do osi obrotu zestawu kołowego, ponieważ wartości kąta nabiegania zestawu są niewielkie. W punkcie styku B koła z szyną oprócz siły prowadzącej $\mathrm{Y}$ oraz siły pionowego nacisku Q działa również siła tarcia, wynikająca ze zjawiska poślizgu obrzeża na główce szyny. Koło zacznie unosić się na główce szyny gdy wypadkowa suma rzutów sił na płaszczyznę obrzeża koła w przekroju B-B będzie działała ku górze. Prędkość ruchu ślizgowego punktu $B$ jest prostopadła do odcinka BA, przez co tworzy kąt $\beta_{u}$ z płaszczyzną pionowa, przechodzącą przez punkt $B$. Dlatego też siłę nacisku $\mathrm{Z}$ przekroju B-B, potrzebną do wyznaczenia siły tarcia należy zrzutować na płaszczyzną odchyloną o kąt $\beta_{u}$ od płaszczyzny pionowej. Równanie równowagi sił $\mathrm{w}$ punkcie styku B zostało przedstawione we wzorze (38).

$$
-Q \cdot \sin \gamma+Y \cdot \cos \gamma+(Y \cdot \sin \gamma+Q \cdot \cos \gamma) \cdot \cos \beta_{u} \cdot \mu
$$

Kąt $\beta_{u}$, zgodnie z rys. 6.8., można wyznaczyć z następującej zależności:

$$
\operatorname{tg} \beta_{u}=\frac{\Delta h}{(r+\Delta h) \cdot \sin \psi}=\frac{\Delta h}{(r+\Delta h) \cdot \operatorname{tg} \alpha \cdot \operatorname{tg} \gamma}
$$
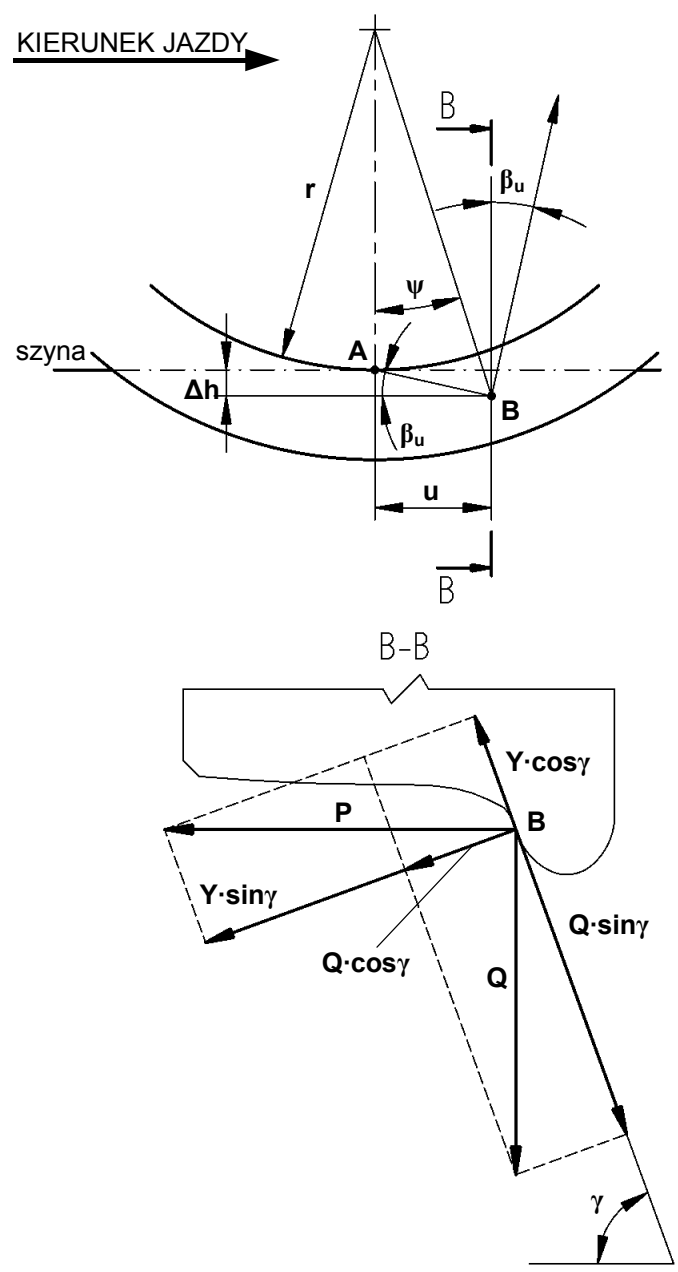

Rys. 6.8. Istota kąta $\beta_{u}$ oraz siły w punkcie styku koła z szyna.
Przekształcając równanie (38) można wyznaczyć siłe prowadzącą Y, której przekroczenie spowoduje unoszenie koła i zwiększone prawdopodobieństwo wykolejenia:

$$
Y=Q \cdot \frac{\sin \gamma-\mu \cdot \cos \gamma \cdot \cos \beta_{u}}{\cos \gamma+\mu \cdot \sin \gamma \cdot \cos \beta_{u}}=Q \cdot \frac{\operatorname{tg} \gamma-\mu \cdot \cos \beta_{u}}{1+\mu \cdot \operatorname{tg} \gamma \cdot \cos \beta_{u}}
$$

Ostateczny graniczny stosunek siły prowadzącej do siły pionowego nacisku ( $\mathrm{z}$ uwzględnieniem kąta nabiegania zestawu kołowego na szynę) będzie miał postać następującą:

$$
\left(\frac{Y}{Q}\right)_{\text {nieb, } \alpha}=\frac{\operatorname{tg} \gamma-\mu \cdot \cos \beta_{u}}{1+\mu \cdot \operatorname{tg} \gamma \cdot \cos \beta_{u}}
$$

\section{Symulacyjne wyznaczanie przebiegu wspól- czynnika Y/Q}

Dynamiczny rozwój komputerów w latach 90 . ubiegłego wieku spowodował wzrost zainteresowania oprogramowaniem symulacyjnym oraz do wspomagania konstruowania. Dotyczyło to również branży przemysłu kolejowego. Obecnie komputerowe wspomaganie projektowania konstrukcji pojazdu jest nieodłącznym elementem na każdym etapie tworzenia pojazdu szynowego.

Rozpowszechnieniu uległy różnorodne programy symulacyjne dynamiki pojazdu, także dla wąskiej dziedziny jaką są pojazdy szynowe. Do wiodących systemów symulacyjnych należą VAMPIRE, ADAMS/Rail, AutoDYN oraz SIMPACK.

Zdecydowaną zaletą współczesnych komputerowych systemów symulacyjnych jest graficzna reprezentacja wyników obliczeń w postaci tabel, wykresów oraz animacji modelowanych pojazdów. Stanowi to znaczne uproszczenie i skrócenie procesu projektowania $\mathrm{z}$ racji szybkiej możliwości wykrycia potencjalnych błędów i ich eliminacji jeszcze przed wyprodukowaniem prototypu pojazdu.

Dzięki zastosowaniu techniki komputerowej wykonywanie skomplikowanych obliczeń współczynnika bezpieczeństwa przed wykolejeniem w zależności od położenia pojazdu na torze wichrowatym zostało znacznie uproszczone. Przykładowy model pojazdu do obliczeń $\mathrm{w}$ programie SIMPACK oraz przebieg współczynnika Y/Q w funkcji długości toru przedstawiono na rys. 7.1. oraz 7.2.

Otrzymane wyniki stanowią pomoc przy weryfikacji przyjętych założeń i zastosowanych w danej konstrukcji rozwiązań. Dzięki nim możliwe jest skrócenie czasu przebywania pojazdu prototypowego na badaniach. Należy jednak od razu zaznaczyć, że nie jest możliwe zastąpienie badań w warunkach rzeczywistych badaniami symulacyjnymi, co zostało określone w normach i kartach UIC. $[4,5,6]$ 


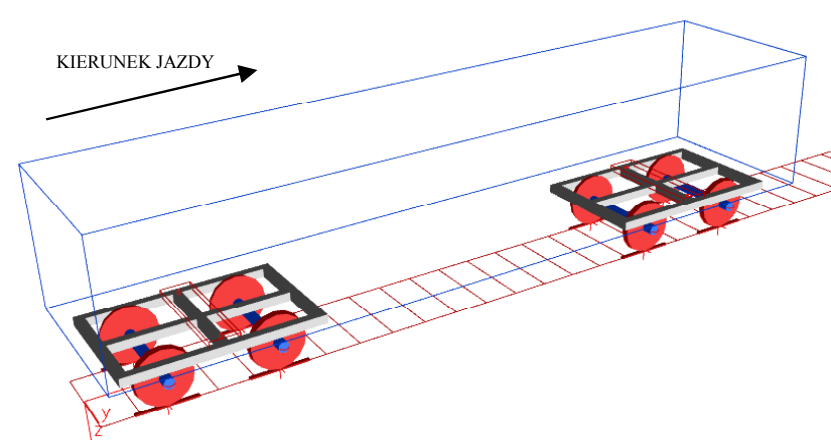

Rys. 7.1. Model wagonu towarowego typu 438W z wózkami Y25LSd1 do badań symulacyjnych w programie SIMPACK [1]

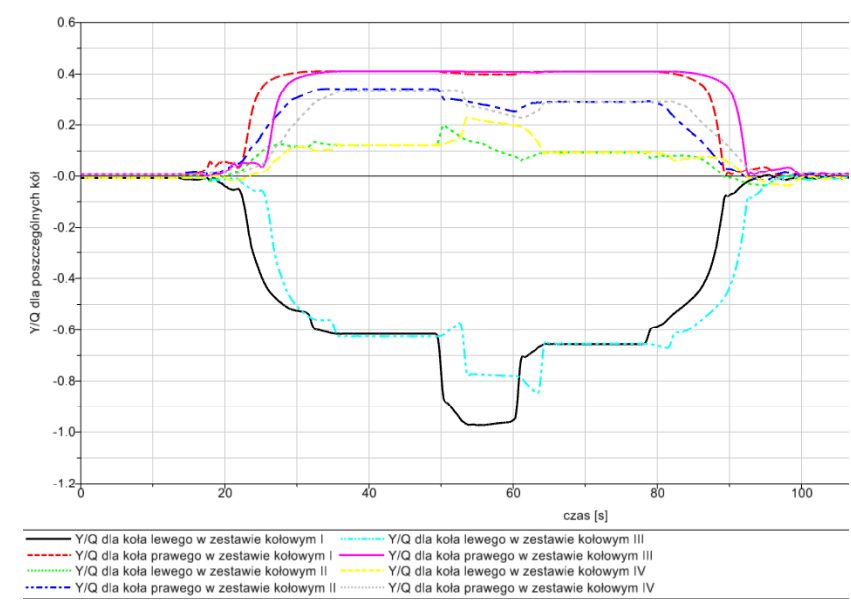

Rys. 7.2. Przebieg współczynnika Y/Q w funkcji długości toru wichrowatego dla poszczególnych kół wagonu towarowego typu $438 \mathrm{~W}$ [1]

\section{Podsumowanie}

Określenie bezpieczeństwa przed wykolejeniem jest jednym $\mathrm{z}$ wymogów badań homologacyjnych dla nowych oraz modernizowanych pojazdów. Zakres oraz rodzaje badań doświadczalnych, prowadzących do wyznaczenia stosunku siły prowadzącej do siły pionowego nacisku określa norma europejska PNEN 14363:2007 [4], mająca status polskiej normy. Informacje $\mathrm{w}$ niej zawarte $\mathrm{w}$ dużej mierze opierają się na doświadczeniach wielu zarządów kolejowych, przeprowadzających badania doświadczalne, z których raport sporządziła grupa badawcza B55, wchodzącą w skład ORE/ERRI. Znormalizowanie wymagań dotyczących kryterium bezpieczeństwa przed wykolejeniem zmniejszyło ilość wykolejeń spowodowanych zejściem koła z szyny pod wpływem zbyt dużej siły prowadzącej lub zbyt dużego odciążenia koła. W obecnych czasach wykolejenia powodowane są najczęściej uszkodzeniami taboru lub infrastruktury kolejowej. Dlatego też istniejące przepisy określające kryteria bezpieczeństwa przed wykolejeniem spełniają swoje zadanie w sposób zadowalający.

\section{LITERATURA}

[1] Kalinowski D., Bezpieczeństwo przeciw wykolejeniu wózka towarowego Y25LSd1 na podstawie badań symulacyjnych, praca magisterska, Poznań $2012 r$.

[2] Prud'homme A., Resistance of the Track to Lateral Loads Exerted by Rolling Stock, Revue Generale des Chemins de Fer, styczeń 1967

[3] Tatara F., Sobaś J., Analiza geometrycznostatyczna biegu pojazdów szynowych na tukach, Wydawnictwo Politechniki Poznańskiej, Poznań $1967 r$.

[4] PN-EN 14363:2007, Kolejnictwo. Badania właściwości dynamicznych pojazdów szynowych przed dopuszczeniem do ruchu. Badanie właściwości biegowych i próby stacjonarne.

[5] Karta UIC 518, Badania ruchowe i dopuszczenie pojazdów szynowych - Bezpieczeństwo jazdy - Obciqżenie toru $i$ własności dynamiczne, $2009 \mathrm{r}$.

[6] Karta UIC 530-2 Wagony towarowe - Bezpieczeństwo jazdy, $2008 \mathrm{r}$.

[7] Raport ORE/ERRI B55 Rp.8 - Prevention of derailment of goods wagon on distorted tracks, kwiecień 1983

[8] 2008/232/WE, Decyzja Komisji z dn. 21 lutego 2008 r. dotyczqca specyfikacji technicznej interoperacyjności podsystemu „Tabor” transeuropejskiego systemu kolei dużych prędkości

[9] 2006/861/WE, Decyzja Komisji z dn. 28 lipca 2006 $r$. dotyczqca technicznej specyfikacji dla interoperacyjności odnoszacej się do podsystemu „Tabor kolejowy - wagony towarowe" transeuropejskiego systemu kolei konwencjonalnych

[10] 2011/291/UE, Decyzja Komisji z dn. 26 kwietnia 2011 r. w sprawie technicznej specyfikacji interoperacyjności odnoszacej się do podsystemu „Tabor - lokomotywy i tabor pasażerski" w transeuropejskim systemie kolei konwencjonalnych 